\title{
Analyzing the profile of the manager from the perspective of the employees: a case study
}

André Philippi Gonzaga de Albuquerque ${ }^{1}$ (D), Fagner José Coutinho de Melo ${ }^{2}$ (D), Larissa de Arruda Xavier $^{1}$ (D), Denise Dumke de Medeiros ${ }^{1}$ (D)

${ }^{1}$ Federal University of Pernambuco - UFPE, Production Engineering Department, Recife, PE, Brazil.

University of Pernambuco - UFE, Business Department, Recife, PE, Brazil.

How to cite: Albuquerque, A. P., Melo, F. J. C., \& Xavier, L. A. (2022), “Analyzing the profile of the manager from the perspective of the employees: a case study", Brazilian Journal of Operations \& Production Management, Vol. 19, No. 1, e2022930. https://doi.org/ 10.14488/BJOPM.2021.032

\section{ABSTRACT}

Goal: This paper proposes to study the leader's profile using the Johari Window to establish feedback on the leader's behavior in comparison with the employees' point of view.

Design / Methodology / Approach: The case study was carried out in a given material distribution center for civil construction through a questionnaire, based on the Johari window model. The research was classified as applied, exploratory, qualitative and case study.

Results: Most of the respondents in the surveyed sector have the opinion that their leader is inserted in the "blind" area of Johari window, that is, it is an area unknown to the leader, either because subordinates do not want to share feedback or because the leader is not able or does not care about it. Through these results, improvements were proposed.

Limitations of the investigation: The questionnaire was only applied in one moment, and it is not possible to compare the leader's Johari window with the posterior view of each team member.

Practical implications: When leaders share their way of thinking and acting and are willing to receive feedback, there will be greater clarity in communication and executing objectives. With this, it is possible to obtain more qualified and motivated personnel for the performance of the organization's activities, reducing costs, increasing productivity, generating a competitive advantage.

Originality / Value: Understanding the relationship between the leader and followers in the researched sector, verifying the confrontation of the opinion of the followers about the behavior of the leader in order to improve the organizational environment to achieve the objectives.

Keywords: Leadership; Feedback; Johari Window model.

\section{INTRODUCTION}

Leadership is a matter of paramount importance in organizations, whether public or private. Companies have sought increasingly absorbing their leaders the compentências and skills they available (Pereira et al. 2017; Ferreira et al., 2019; Barreto and Nassif, 2014; Koca and Erigüç, 2020; Virtaharju and Liiri, 2019).

Today the leader plays a very important role in directing human capital and can lead them to significant change. According to (Cherman and Pinto, 2016), the contribution of individual knowledge in organizational knowledge is very low and can cause frustration on the part of the subordinate. The leader's challenge remains the ability to communicate with his team.

Financial support: The authors are grateful for the support received to conduct this study from the Foundation for Science and Technology of Pernambuco (FACEPE), the Coordination for the Improvement of Higher Education Personnel (CAPES) Financing Code 001, the Brazilian governmental entities that promote scientific and technological development.

Conflict of interest: The authors have no conflict of interest to declare.

Corresponding author: andre_philippi@hotmail.com

Received: 19 Feb 2020.

Approved: 11 Apr 2021

Editor: Julio Vieira Neto. 
The organizational culture having the mission, vision and objectives as a set of values of an organization needs to be shared among its managers and employees in order to achieve the strategic objective. This can be achieved through cultural alignment between the leadership and the team (Russo and Tomei, 2015).

Therefore, the present study addresses the feedback that must occur between the leader and the suborndinados in order to obtain a better harmony in the work environment. For this, a questionnaire was used and data were analyzed through Johari window, a human capital training and management model.

The contribution and originality of this research is due to the fact that it studies the leader's behavior and profile based on the perceptions that employees have about the leader's attitudes within the organization. In addition, the research aims to confront the opinions of the leader and the followers with the purpose of seeking consonance in their perceptions. Otherwise, identify the gaps present in these impressions and propose improvements.

Often the leader has a perception of doing a good job simply because he is achieving goals. What goes unnoticed is that your employees may be doing work out of obligation, not being spontaneous. This can make the relationship between them increasingly weakened. The problem is that sometimes even the leaders do not know that the workers are dissatisfied with their leadership.

In this context, this research intends to study in a distribution center the profile of the leader applying the Johari window to establish the degree of feedback on the behavior of the leader according to his perception and the vision of your employees to improve his leadership. According to Rodrigues and Veloso (2013), it is expected that the greater the perception that the leader is trustworthy, the more likely he is to trust him.

This work is divided into five sections. This section presents the context of the problem and the objectives. The second section reports the methodology with the characteristics and classification of the research. In the third section, there is the theoretical framework addressing the concepts and contexts about Leadership and the Johari window model, as well as the way data collection and preparation was carried out in relation to the questionnaire applied in the researched company.

The fourth section presents the analysis of the results of the research and some recommendations as a way of improvement for organizations. In section 5 are the conclusions, as well as the main difficulties and limitations of this research.

\section{METHODOLOGY}

For this study, a research was carried out applied to a material distribution center for civil construction, with the objective of using its results to propose improvements in the company's day-to-day activities.

As for the purposes, the research is exploratory, which according to Gil (2008) is that research whose objective provides greater familiarity with the problem, in order to make it more explicit or to build hypotheses. It can be said that these researches have as main objective the improvement of ideas or the discovery of intuitions. Its planning is, therefore, very flexible so that it allows the consideration of the most varied aspects related to the studied fact.

The study is considered as a qualitative methods research because it does not use statistical models. According to Miguel (2018), qualitative research does not seek generalization. Thus, data analysis will aim to simply understand a phenomenon in its most intense sense, instead of producing inferences that may lead to the constitution of general laws or extrapolations that allow us to make valid predictions about the future reality.

According to Yin (2015) the case study is characterized by the in-depth analysis of an object or group of objects, which can be individuals or organizations. The assumption of this study is that, when one knows very well how the phenomenon occurs in one or a few 
individuals, companies or situations, one can take hypotheses about how the phenomenon occurs in general.

The research is considered, according to the number of data, a unique case study because it is applied in a material distribution center for civil construction. The validity of the present research construct is the perception of the relationship between the leader profile and employees in the distribution center, which will be verified through two structured questionnaires, one applied to leaders and another applied to employees. In addition to the questionnaires applied, consultations will be made to documents related to the leadership network and hierarchy in the company.

The case study was carried out at a material distribution center for civil construction. The company stores its products by segments which are: paints, ceramics, doors, bags (cement, mortar), wires, sanitary wares, electrical and hydraulic switches, models, motors.

The model used for the analysis of the research was the Johari Window. The respondent should attach to each situation the 5 complete points between alternatives $A$ and $B$. The assignments of these points followed a variation between the minimum score (zero) indicating that it does not correspond to the leader's attitude in that situation, up to the maximum score (five) which accurately describes the behavior of the leader on the given occasion. In the questionnaire developed by Fritzen (1985) and used by Heringer (2010), the subordinates responsered to each situation putting in its place the way of thinking that its leader would act in the situations mentioned. Then the leader would respond within the situations, how he would behave.

This questionnaire has 10 questions related to feedback receptivity (feedback information) regarding the leader and 10 questions available to the leader to provide feedback. After applying the questionnaire, we placed a score of these questions placed on a scoreboard used by Heringer (2010). From there, coordinated pairs are formed providing the location of the leader, in the opinion of the subordinates and in the opinion of the leader himself between the quadrants of the Johari Window.

Previously, it was verified with the manager responsible for the sectors in that distribution center the availability of the purchasing sector to carryout the questionnaires. In the purchasing sector there was only one leader (purchasing director) and 6 subordinates (all purchasing assistants). Of these, the 5 leaders were present and answered the questionnaire. The leader who was absent was having a medical intervention and therefore had to leave, but the next day, as soon as he arrived, he completed questionnaire without having any contact with the other interviewees so that there would be no communication about the questionnaire.

The leader was in a meeting at the time the followers were answering the questionnaire. At the end of the meeting, he filled out the questionnaire that was prepared by Heringer (2010), expressing the opinions about each situation presented.

Thereby, it is worth noting that the composition of the sample of this research were six leaders (all employees of the purchasing sector) and a leader of the purchasing sector of the distribution center. The application of the proposed approach at the material distribution center for civil construction pointed out that the sample is representative of the researched sample universe. It is worth noting that the results obtained in this study were a consequence of the sample characteristics. It is important to point out that the organization and the sector studied were selected by convenience of the researchers.

\section{LITERATURA REVIEW}

Contextualizing this research is verified by the discussion of the key concepts for the understanding of how the behavior and attitudes of the leader can influence perceptions and impressions of their team. Thus will present the concepts of leadership, as well as the definition and structure of the management model Johari Window. 


\subsection{Leadership}

The leadership within organizational environments has mobilized the inetersse numerous scholars. The interest is justified by the importance that it has for organization (van Dick et al., 2018). It seems that advances in the study of organizational leadership and the efforts of researchers in the last century has not been sufficient so that one can understand the breadth and complexity of leadership within the organizational environment (Amaral et al., 2007).

Leadership is the art of mobilizing others to want to struggle for shared aspirations; which is a concept which emphasizes the word "want" because it takes people to do something is not a relatively simple task. To feel the real essence of leadership, ask yourself: What is needed so that people want to engage in an organization in a "voluntary"? What needs to be done so that people show a high level of performance? What can you do to people to remain loyal to the organization? There is a difference between getting support and order, with the true leaders maintaining credibility as a result of their actions - to challenge, inspire, enable, guide and encourage (Kouzes and Posner, 1995).

It is important to mention about the difference between leadership and management. For Hersey and Blanchard (1986), management is a special type of leadership that prevails the achievement of organizational objectives. Every time we try to influence the behavior of a person, we are practicing leadership. It is therefore clear that not every leadership behavior refers to the achievement of organizational objectives. The main objective of leadership is to create a shared vision of the future (Oliveira et al., 2015).

\subsection{Johari Window Model}

Hersey and Blanchard (1986) aimed to help leaders to develop people's potential. This can imply a change in leadership style when necessary. This continuous change in style requires leaders to be more flexible. These studies were carried out at the Center for Leadership Studies for more than ten years of using the Leader Effectiveness and Adaptability Description (LEAD) instruments.

It is easy to tell managers that they should apply the theory and results of behavioral research to develop diagnostic skills to increase their effectiveness. The difficult thing is to implement this. Even with good diagnostic skills, leaders need to adapt their leadership styles to the demands of the environment.In this context, the situational leadership model, proposed by the aforementioned authors, is based on the combination of three variables: leader style, leader maturity and situation in which the leader must fulfill a task.

Thereby, in order for the leader to be sure that the followers are understanding the instructions, managers have the possibility to check for any significant discrepancies between the way they see their leadership style themselves and how their followers see it. When analyzing and communicating this data to participating managers, a very useful framework developed by Joseph Luft and Harry Inghan is used: Johari Window, a name given by combining the first names of its creators.

In studies by Lima (2012) one of the main qualities expected of a leader is the knowledge of human nature, which leads him to realize and understand what your initial situation facing the controlled, that is, how it is perceived and accepted in Desktop. An excellent management model that can be used for the leader to know the opinion of their team about it is the Johari Window. According to Luft (1970), the Johari Window can be applied in the relations within the group. To the surprise of Luft and Ingham (1955), creators of the Johari Window, many students and non-professional workers were inspired by this scheme to better understand human relations. 


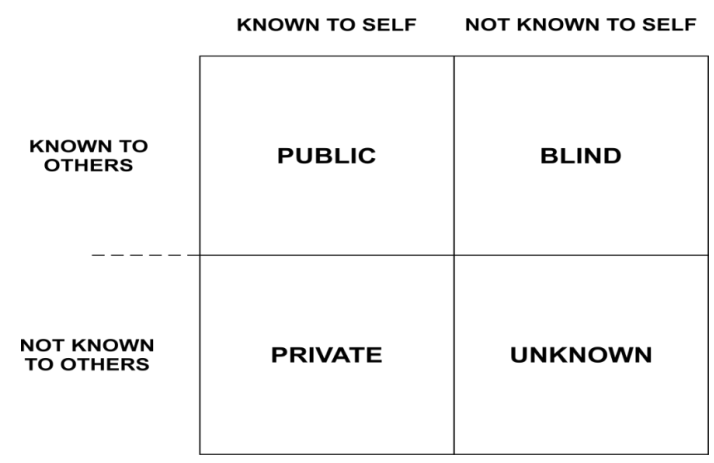

Figure 1. Johari Window Model.

Source: Adapted from Hersey and Blanchard (1986).

For Hersey and Blanchard (1986), the Johari Window is used to represent the main personality and not the general personality, according Figure 1. The difference between leadership personality and leadership style according to these authors, is that the leading personality includes self-perception and the perception of others; leadership style consists only of the leadership behavior of an individual as seen by others, this is at the top, by subordinates, by colleagues, etc. Thus the leadership personality is equal to more perception perception of others (style).

The area known for you (leader) and for others in any particular organizational context is called public area: it is known to all (leader and others, this is superior, subordinates and colleagues) within this organizational context.

The area unknown to you (leader), but known to others, is called the blind area. It is unknown to the leader or because subordinates do not want to share feedback or communicate ("level") with the leader about the impression he gives to others, either because the data may exist in terms of nonverbal and verbal responses, but leader is unable or unwilling to "see" them.

The area is known by the leader, but unknown to others is a private call area because it is the only knowledge of the leader. It may be private because it did not want to share it or refer it to other members of the organization, or because others do not capture the verbal and non-verbal responses of the existing system leader.

The last area, unknown both to the leader and to others, is called unknown. Freud describes the character as something like an iceberg. A part of the personality of a leader is above the surface and is visible. Who wants to look at it can not fail to see its basic dimensions, its strength, its constitution and its configuration. But most of the iceberg lies below the surface and do not make a conscious effort to know it, we will never have an exact idea of their reality. However, much of the personality of an unknown call leader can have a decisive influence on the types of behavior he adopts, to try to influence the behavior of others.

For Littlejohn (1978) the Johari Window draws attention to those aspects of the person are known and for those outside of conscious awareness. But more importantly, from a communication point of view, it is that emphasizes changes in awareness that occur over time. Ideally, the Quadrant I should increase in size with communication. If communication is good, the revelation occurs, shifting feelings and Quadrant III behavior for Quadrant I. Good communication also involves feedback, which makes the feelings and behaviors move from Quadrant II to Quadrant I. The area unknown Quadrant IV is hard to find, but may become known in retrospect through reflection, of certain drugs, the projective techniques and dreaming.

Among the applicability checks the Johari Window one could find the studies of Ang (2016), which reports on a mentor-apprentice consultation system (MEMOC - mentor-mentee consultation system) which aims to carry out a monitoring to provide advice based on problems giving support to undergraduate students and graduate. The study used categorizing people into three types of users: the supervisor, the students active and passive 
students. Since then used the Johari window, also known as array of self-revelation, to explain about the mentor's role in providing feedback to students. Overall, the said survey results show the satisfaction of teachers and students with this system (MEMOC) and reported that will use the system in the future in terms of attitude and perceived usefulness.

Table 1 below shows the main and current studies involving Johari's Window and its applications.

Table 1 - main articles currently published

\begin{tabular}{cc}
\hline Topic & Authors \\
\hline Feedback among researchers & Ha (2019) \\
Profile of the leader on the social networks & Gamayanto et al. (2019a) \\
\cline { 2 - 2 } Communication between tutors and students & Gamayanto et al. (2018) \\
\cline { 2 - 2 } $\begin{array}{c}\text { Understanding and awareness of themselves } \\
\text { and others }\end{array}$ & Gamayanto et al. (2019b) \\
& Gamayanto et al. (2020) \\
Communication skills of healthcare professionals (2020), Tseng et al. (2018), Lowes (2020), & Suryani and Siregar (2020) \\
Self-disclosure on social networks & Osmanoğlu (2019) \\
Digital Humanities & Beganovic et al. (2019), Jinto and Tessy (2020), \\
Koca and Erigüç, (2020)
\end{tabular}

\section{RESULTS}

From the analysis of the questionnaires applied, the results demonstrate that the interviewees have different opinions about the leader because of the experience of each one in the earch industry.

It was observed that two employees had similar opinions on the leader. Through the situations presented in the questionnaire, their opinions made to the leader was inserted in the "Public" quadrant as shown in Figures 2 and 3 below.

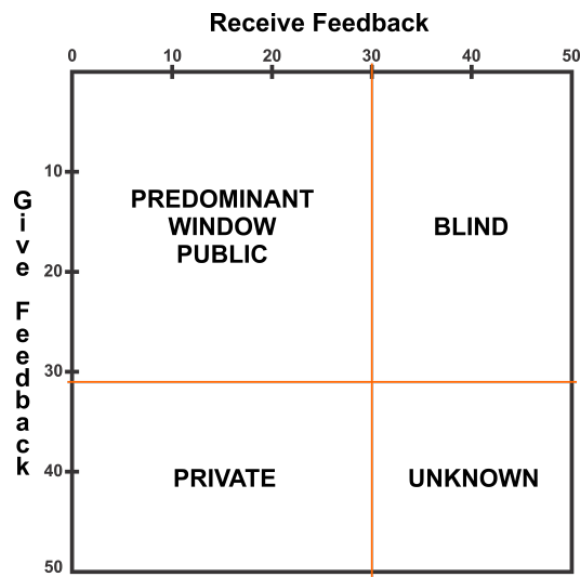

Figure 2. Johari window to the interviewed 2 


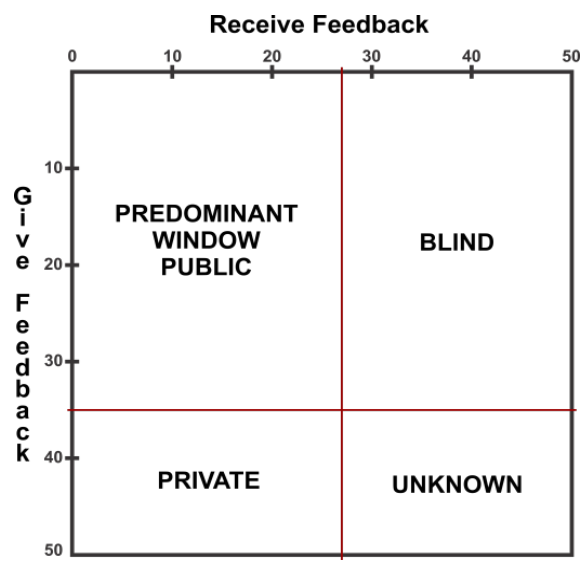

Figure 3. Johari window to the interviewed 6

This may have occurred due to the length of time these employees worked in the corporation, as these employees are the oldest in the industry, not only in the company but also in the sector in which they perform their tasks. Therefore, it is believed that they know more about their leader because they have more time on the job than others, they have more opportunities to assist him in everyday situations, so judge him that way.

Because it is a public area, which is characterized by being a profile known to everyone in that organizational context. That can be seen through the graph that shows that in this area of the window there is the possibility of giving and receiving feedback. An area characterized by the free exchange of information.

Feedback is an important part of the relationship between leader and followers, and if carried out frequently, it can promote personal development and reinforce which employee performance will lead to the success and growth of the corporation (Koltz and Odegard, 2020).

The other four respondents, and therefore the majority of respondents, think that the leader does not provide the feedback he should have. For this reason, through his opinions, he inserted him in the window Johari quadrant corresponding to the "Blind" area. It can be seen from this result in Figures 4, 5, 6 and 7 below.

In the blind area, there may be a lack of communication due to the failure of feedback in the leader's relationship with the team.

According to the graphs, the contact is very easy to give feedback concerning the receptivity of the same. These employees are younger in the company and the sector, and this may be an indication that they did not have as many opportunities in their daily lives to meet their leader. Respondent 4, for example, is less time-consuming in the sector and the quadrant of the blind area in which he fit as a leader was the largest of all.

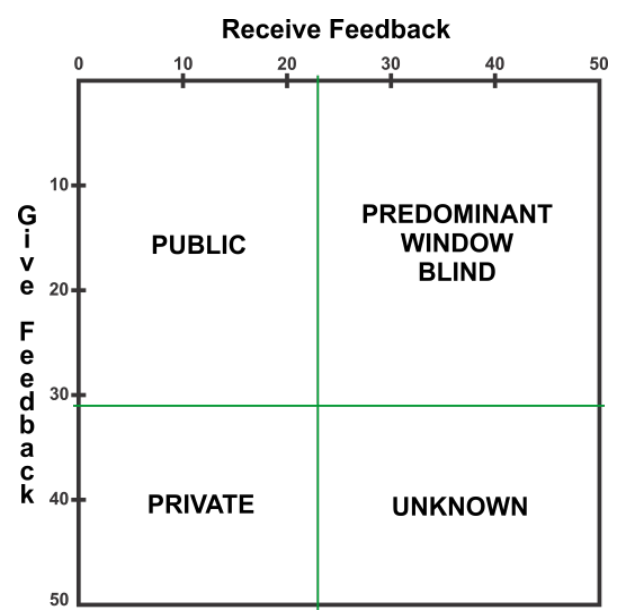

Figure 4. Johari window to the interviewed 3 


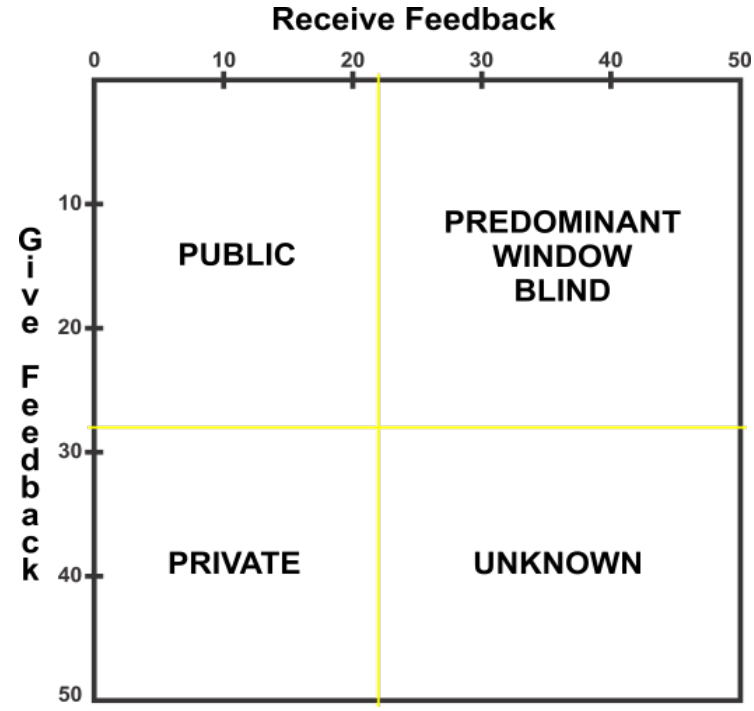

Figure 5. Johari window to the interviewed 1

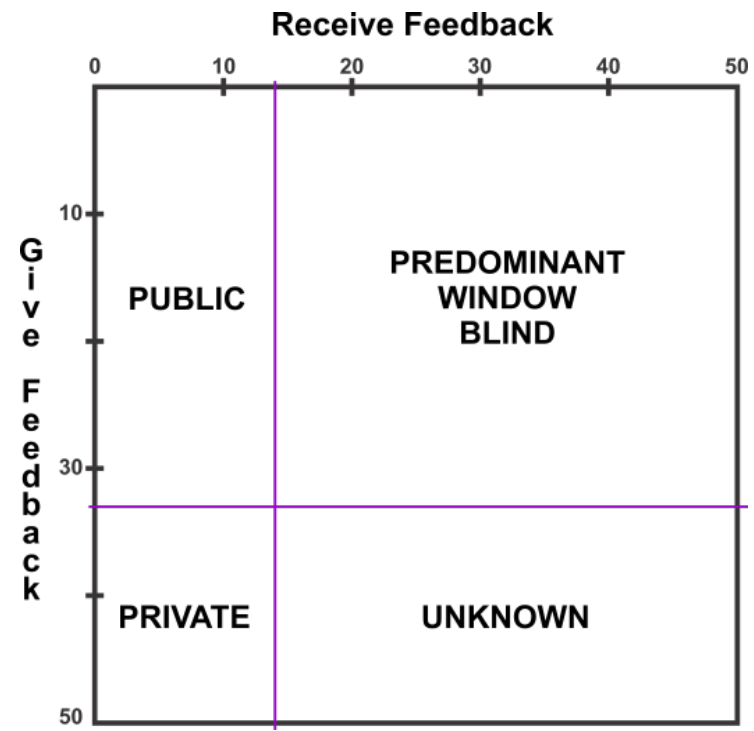

Figure 6. Johari window to the interviewed 4

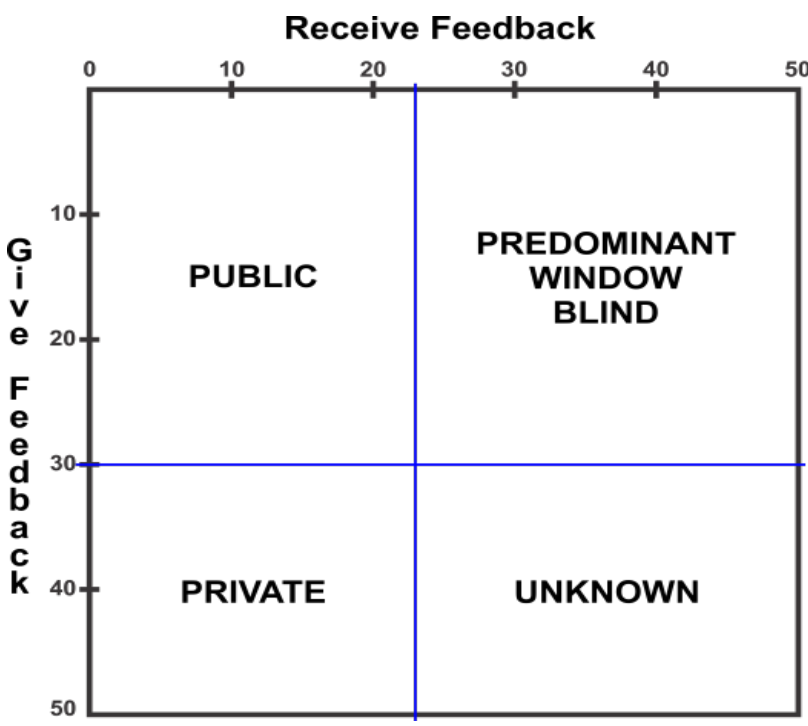

Figure 7. Johari window to the interviewed 5 
In Figure 8 below, it shows the opinion of all respondents superimposed on a single Johari Window. Each participant has a line with a different colour for better visualization and clarity. From this figure, you can see that the horizontal trend greater than the vertical trend may indicate that your leader has a greater tendency to give feedback than to receive.

As feedback is generally seen erroneously, but as a criticism aimed at pointing out errors (Kalra et al., 2020), employees do not have this knowledge or openness to give feedback to the leader.

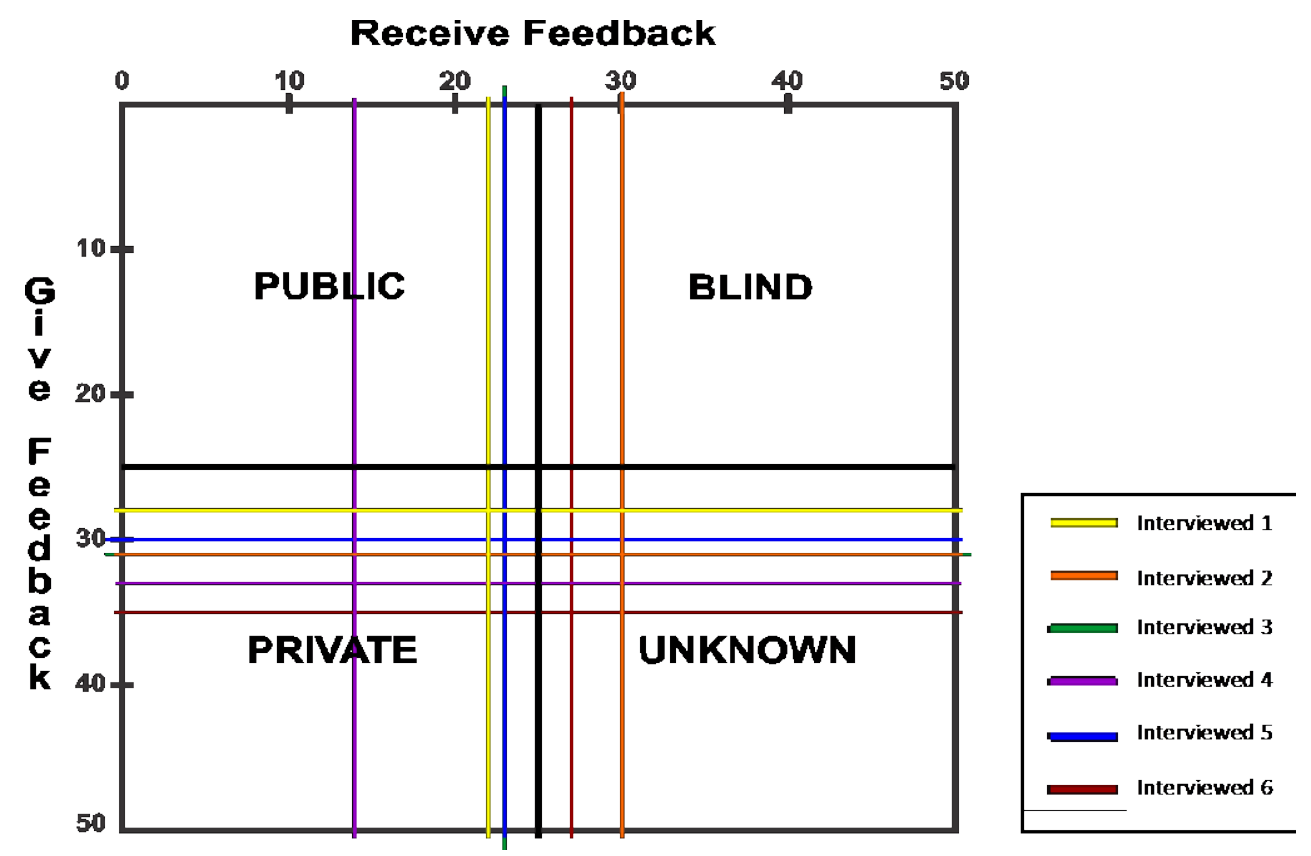

Figure 8. Results of intervieweds superimposed on a single Johari window

\subsection{Predominance of public leadership}

The result of the leader's perception of himself as shown in Figure 9.

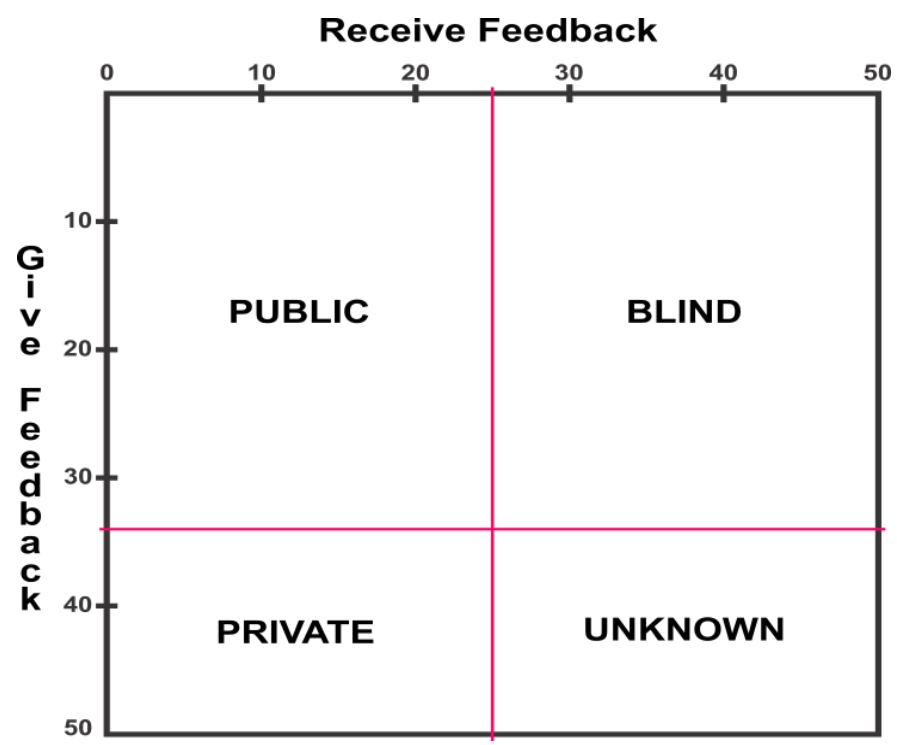

Figure 9. Johari Window for leadership

There was a predominance of two quadrants in the leading Johari window. Interestingly, they are in opposite quadrants say that they respect the variable "Receiving Feedback". With 
this result it is believed that in certain situations the leader, will be able to obtain feedback from his followers. On the other hand, in other situations, it does not seem as accessible to this receptivity as it should be.

Self-perception of leadership is often discrepant when compared to employees' perception of leadership, and reducing these discrepancies can guarantee leadership success (Becker et al., 2002).

Malloy and Janowski (1992) state that a leader who compares self-perceptions of leadership to his employees' perceptions of leadership, can increase the level of selfperception, which can lead to personal development and better communication between the leader and your team.

\subsection{Analysis of Results Found}

For an organizational environment becomes more efficient and friendly it is expected that there is a clear relationship between the leader and the followers. Within the Johari Window that can be described through the public area, where the characteristics of people are recognized by themselves and by others who are around you.

In this study it was investigated by means of questionnaires and results, which led most of the researched sector is of the opinion that their leader is inserted in the blind area of the Johari Window. For this situation can be changed it is recommended that one should increase the public area of that window thereby decreasing the blind and secret area. This can be achieved through two processes that can directly influence these quadrants: the feedback and communication.

The feedback is the degree to which the led are willing to speak out as the leader behaves according to the situations in the organizational environment. Many managers end up repressing and stifling feedback from subordinates questioning your perceptions. The opinions must be heard and accepted, but the behavior should be limited (Hersey and Blanchard,1986).

The increase in feedback relationship with the leading subordinates causes amplification of the public area, as shown in Figure 10, and therefore the decrease in the blind area Johari Window, which is exactly our proposal for improvement. Once the public area is larger, there will include a clearer and more effective communication between the leader and your team.

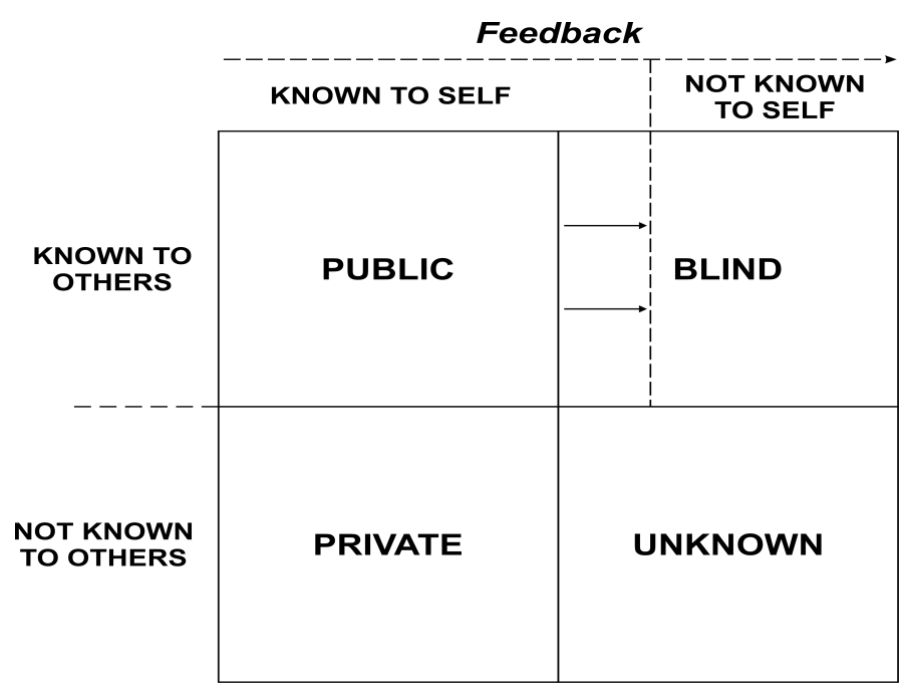

Figure 10. Feedback Effect on the Johari Window. Source: Adapted from Hersey and Blanchard (1986).

Another process that affects the Johari Window is communication. In his Hermida and García studies (Hermida and García, 2016), report that communication seems to be increasingly involved in the production and reproduction processes in every society. It is 
developing a change not only historical, but also a technological revolution mediation to produce, transmit and control the knowledge of the information.

The communication is the measure that leaders are willing to share with their followers what only concern himself. Still in these studies report that the sense used by them is different from some authors of the area (Hersey and Blanchard, 1986; Shamoa-Nir, 2017). For them, the communication goes beyond what people say, but in their behavior. In other words, what really matters is the legal understanding of the values that is behavior. In Figure 11 below shows the simultaneous effect of feedback and communication on the Johari Window.

According to Hersey and Blanchard (1986), there is an interesting phenomenon when there is a simultaneity of feedback and manifestation between leaders and led. Not only the public area begins to extend into the blind and secret areas, but there is high probability that part of what was previously unknown (both for leaders and for their team) begin to emerge on the surface of the public area.

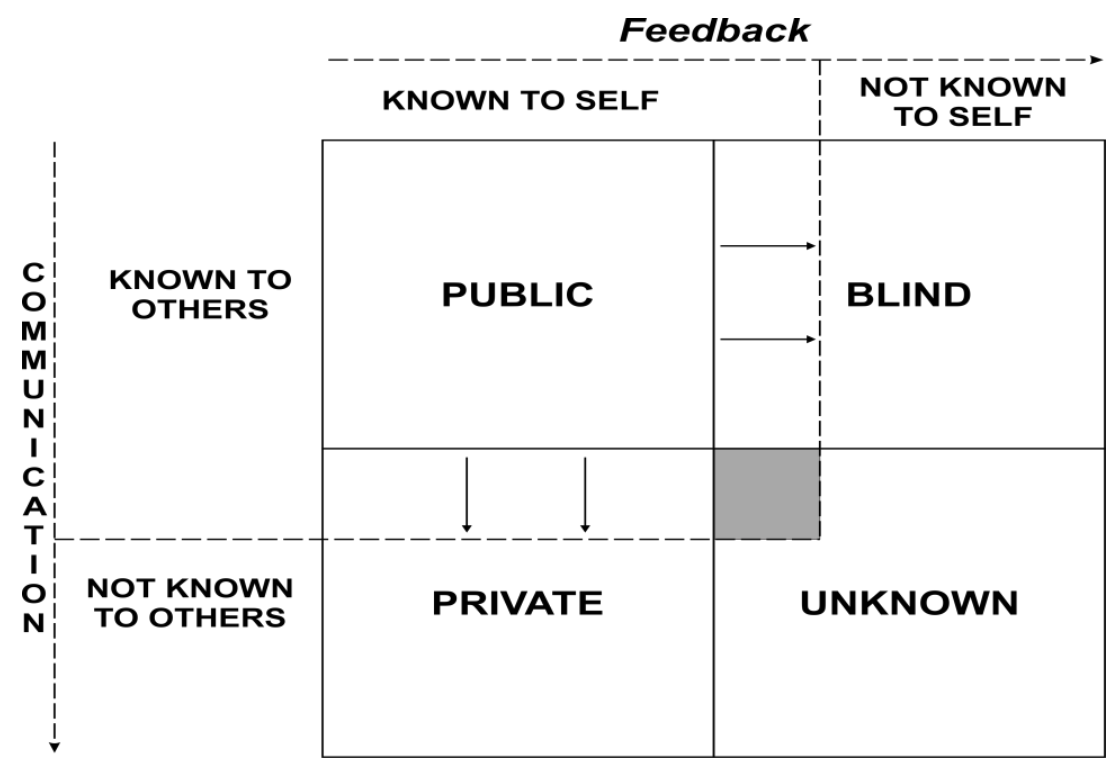

Figure 11. Effect of Feedback and Communication on the Johari Window.

Source: Adapted from Hersey and Blanchard (1986).

In studies of Lamy (2015), the literature review is in line with this research which says that the higher the Public area likely to increase the quality of a relationship and trust. Their results show that the four companies submitted one, the enterprise there was the reverse, that is, a public area smaller than the other surveyed companies may indicate a relationship of trust decline phase. In companies B and C presented the results in line with the literature. In company D Public area it was also higher, but not owned nor Blinded area nor the Unknown. An unexpected result and difficult to explain to the information available, may be related to the limitations in the research.

Within the theme, Cassidy studies the (Cassidy, 2014) provides an overview of each area of the Johari Window adapting the proposed theme and as a result all the discussion the article suggests the use of this model for improving communication between the engineering students. It is also highlighted in the article, the importance of greater public area within the model and the search for feedback to facilitate the opening of the participants involved. The Johari Window helped emphasize self-knowledge, self-disclosure and openness of feedback as simple communication models. In addition, the Johari Window stresses that knowledge comes from a variety of sources, and each interested party can offer a unique view that can be used to improve the skills of those involved.

In line with this research study results of McLaughlin and Luong (2011) showed that the Johari Window assisted in unveiling perceptions before diffuse. Perceptions of designers and 
users are often ignored. This can be reduced due to an imprecise language or different interpretations of usability between two groups. With the modification of the Johari Window to the research context that information that previously was found confused, became interpretable among software designers and end users.

\subsection{Recommendations to the Leader and the Company}

Before any suggestion for the research, it is important that the leader disseminates clearly and objectively within your team mission, vision and values of the organization. The explanation of these concepts brings the closest led the company and can function as a north in times of doubt on what to do.

Seconds studies of Hersey and Blanchard (1986), it is easy to tell leaders what they need to do, but it is difficult that they are able to put this into practice. Often they do not understand what the literature proposes as form of execution or think you can not take into account all that you proposed in a decision as recommended theories.

With the development of studies there was a need for a significant situational model in the leading area. For Hersey and Blanchard (1986), situational leadership is based on an interrelationship between the amount of guidance and direction that the leader offers, the amount of social and emotional support given by the leader and the level of readiness of subordinates on performance a task, function or specific goal. It was a concept developed to help people who try to exercise leadership, regardless of their role, to be more effective in their daily interactions with others. Thus situational leadership describes how people behave taking into account their two dimensions, task behavior and relationship (Hersey \& Blanchard, 1982).

This research proposes as a way of improvement for the company researched, this simultaneity between feedback and demonstration on the Johari Window, consequently, the list of leaders with their followers. From the moment that leaders share their way of thinking and acting toward their subordinates, reveal their behavior in situations of daily life and are willing to receptivity feedback public area of the relationship will become ever greater. With this, there will be greater clarity in leader-led making organizational communication environment is friendly, clear and therefore reach the maximization of pre-defined objectives by the company. In situational leadership the emphasis is on the leader's behavior towards his subordinates. Ensure an efficient flow of feedback is therefore essential to remove the barriers to performance improvements (Lo et al., 2016).

This kind of leadership is ideal to meet the objectives that have been addressed throughout the research. In it the leader should adopt a leadership style with your subordinates depending on the level of maturity that their team face the task they need to perform. Here there is a combination of what the leader wants the led do, setting goals and defining their roles, and as the leader strives to communicate with people, supporting and encouraging them.

Moreover, it is important that the leader periodically do a reassessment regarding the feedback and communication in order to identify the compliance of information and if they are coming clearly, free of obstacles. Leaders need to be able to identify the reality in your environment.

\section{CONCLUSION}

This study set out to verify the opinions and perceptions that led a team have on their leader. Through information obtained from personal data in the first part of the questionnaire, it is believed that officials were more long both the company and the industry know more their leader, because by having more working time that others have they had more opportunities to watch him in situations in daily life.

The opposite is also true. For employees who work less time both in the company and researched sector, judge their leader struggling to give feedback. It is believed to be due to the lower interaction time and, consequently, less time observation on its leader behavior. 
With the advancement of research, collection and analysis of data from the questionnaires, it was found that the objectives were achieved, namely: understanding the leader's relationship working with their team in the surveyed sector and verification of the confrontation of opinion of led with respect to the leader's behavior, as well as improvements to a harmony in the organizational environment.

Through literature was possible to make recommendations relating feedback and clearer communication in relation leader-led so that the opinions and perceptions of the followers are not much different on the perception that the leader himself has on you.

This research found some difficulties in its implementation, but it can not fail to mention distrust in the beginning with respect to the disclosure of the results for their leader or the company's management. So it was necessary that the researchers assert clearly, and repeatedly demonstrate that the data collected and the results would be extremely confidential and would be used only for purposes of this research. Through the confidentiality agreement signed by the authors of this work was achieved the goal of clarity and subsequently the confidence to the questionnaires were answered in the most sincere way, so there is no discrepancy between the results and the reality of this sector in the company consulted.

The main limitation of this study is the fact that the questionnaire was applied only at a certain time the company has not been possible to make the feedback process. And so, after a new period carry out a new collection of data through the same instrument to compose the leader of the Johari Window.

As seen, the application of this model is very wide. It is suggested that it be applied in more areas of expertise in various industry companies, such as schools, hospitals, churches, finally, in any institution or organization that exists this relationship leader-led, so that you can understand how is working the leader's role in relation to their team. Thus, implementing better policies so that this relationship is the most harmonious and beneficial as possible for the entire organization. And this is not only done in the lower levels, because the interesting would that be carried out this kind of research at all levels of the organization.

\section{REFERENCES}

Alvarenga Netto, C.A., Abilio, C.C.C., Coutinho, S.M.V. et al. (2019), "A Janela de Johari como ferramenta de análise da privacidade de dados pessoais", Ciência da Informação, Vol. 48, No. 1, pp. 79-93.

Amaral, D.J., Godoy, A.S., César, A.M.R.V.E.C. et al. (2007), "Diversity of gender and formation of ingroup: a contribution of Leader - Member Exchange Theory - LMX", Review of Business Management, Vol. 9, No. 24, pp. 41-59.

Ang, L.W. (2016), “The Design of Presence and User Testing on Mentor-mentee Consultation System (MEMOC)," in ACM ICPS Proceedings of ChluXiD, Centre for Instructional Technology and Multimedia Universiti Sains, Malaysia, pp. 43-53.

Barreto, J.C. and Nassif, V.M.J. (2014), "Entrepreneurial leaders and the dissemination entrepreneurial orientation", Review of Business Management, Vol. 16, No. 51, pp. 180-98.

Becker, J., Ayman, R. and Korabik, K. (2002), "Discrepancies in self/subordinates' perceptions of leadership behavior: Leader's gender, organizational context, and leader's self-monitoring", Group \& Organization Management, Vol. 27, No. 2, pp. 226-44.

Cassidy, T.M. (2014), Opening the Window to Lifelong Learning: Applying the Johari Window Framework in Engineering Communication Curriculum, Manhattan, Kansas State University, pp. 1-4.

Cherman, A. and Pinto, S.R.R. (2016), "Valuing od Knowledge in Organizations and its Embedding into Organizational Pratices and Routines", Review of Business Management, Vol. 18, No. 61, pp. 416-35.

Churn, P. (2019), "The tree of training", Education for Primary Care, Vol. 30, No. 4, pp. 243-5.

Cruz, C. (2020), "Real talk: using song lyrics to teach perception and the Johari Window", Communication Teacher, Vol. 34, No. 2, pp. 131-5.

Esterle, L. and Brown, J.N.A. (2020), "The competence awareness window: knowing what I can and cannot do," in IEEE International Conference on Autonomic Computing and Self-Organizing Systems Companion (ACSOS-C), IEEE, Washington, DC, USA, pp. 62-3. 
Ferreira, S., Neto, J. and Batista, H. (2019), "Critical success factors on project and process management in competitive strategy implementation", Brazilian Journal of Operations \& Production Management, Vol. 16, No. 4, pp. 605-16.

Fritzen, S.J. (1985). Janela de Johari: Exercícios Vivenciais de Dinâmica de Grupo, Relações Humanas e de Sensibilidade, Vozes, Petrópolis.

Gamayanto, C., Christian, H., Wibowo, S. et al. (2018), “Developing “Culture Intelligence (CI3) Framework” Inside Social Media Using Johari Window Methods", Indonesian Journal of Information Systems, vol. 1, n. 1, pp. 1-12.

Gamayanto, C., Wibowo, S. and Purnamasari, S. (2019a), “Developing “Leadership Intelligence (CI2) Framework" Inside Social Media to Develop an Ethical Leader using the Johari Window Method", Indonesian Journal of Information Systems, vol. 1, n. 2, pp. 119.

Gamayanto, I., Setiadi, R.I.M., Muljono, M. et al. (2019b), "The Concept of "Anti-Hoax Intelligence (Cl1)" Inside Social Media using Ken Watanabe \& Johari Window Methods", International Seminar on Application for Technology of Information and Communication (iSemantic), Semarang, Indonesia, pp. 528-35

Gamayanto, I., Wibowo, S. and Setiadi, R.I.M. (2020), “Developing "Anti-Cyberbullying Intelligence" Inside Social Media Using Johari Window-Ken Watanabe-Problem Solving 101 Methods", Journal of Art, Design, Education and Culture Studies, vol. 5, n. 2, pp. 114-25.

Gil, A.C. (2008). Métodos e Técnicas de Pesquisa Social, Atlas, São Paulo.

Ha, K.M. (2019), "Integrating the resources of Korean disaster management research via the Johari window", Evaluation and Program Planning, Vol. 77, pp. 101724.

Heringer, T.F. (2010). Relação entre as Variáveis, Relacionamento Interpessoal e Clima Psicológico: Um Estudo no Setor Industrial da Empresa Alfa, Dissertação de Mestrado em Ciências Contáveis, Fundação Instituto Capixaba de Pesquisas em Contabilidade, Economia e Finanças - FUCAPE, Vitória, ES.

Hermida, O.V. and García, F.B. (2016). "Innovaciones comunicativas y cambios de los sistemas socioeconómicos. interpretaciones de sus efectos em los textos científicos", Revista de Estudos Sociales, vol. 56, pp. 67-79.

Hersey, P. and Blanchard, K.H. (1982a), "Leadership style: attitudes and behaviors", Training and Development Journal, Vol. 36, No. 5, pp. 50-2.

Hersey, P. and Blanchard, K.H. (1982b), Management of Organizational Behavior - Utilizing Human Resources, 4th ed., Prentice Hall, Hoboken.

Hersey, P. and Blanchard, K. (1986), Psicologia para Administradores: a Teoria e as Técnicas da Liderança Situacional, EPU, São Paulo.

Hidalgo, E.S., Wandl-Vogt, E., Dorn, A. et al. (2019), “Mapping uncertainty around research data: a Digital Humanities transdisciplinary perspective adopting the Johari window", in TEEM'19: proceedings of the seventh international conference on technological ecosystems for enhancing multiculturality, New York, NY, USA, pp. 804-9.

Hodza-Beganovic, R., Berggren, P., Hugelius, K. et al. (2019), "Survey-based experiential learning - means of raising professional awareness in developing countries", European Journal of Public Health, Vol. 29, No. 4, pp. 586.

Jinto, M. and Tessy, S. (2020), "Johari window model a self-disclosure process to promote the teamwork", TNNMC Journal of Mental Health Nursing, Vol. 8, No. 1, pp. 25-9.

Kalra, J., Mahajan, R. and Singh, T. (2020), "Preparing for feedback in context of competency based medical education undergraduate training in India", South-East Asian Journal of Medical Education, Vol. 14, No. 2, pp. 3.

Koca, G.S. and Erigüç, G. (2020), "The effects of communication skills levels of health professionals on the dimensions of the Johari Window model", International Journal of Healthcare Management, Vol. 13, Suppl 1, pp. 434-46.

Koltz, R. L. and Odegard, M. (2020). Feedback: The Foundation of Kind Leadership, Stanford University, Stanford.

Kouzes, J.M. and Posner, B.Z. (1995). The Leadership Challeng, 2nd ed., San Francisco, Jossey- Bass.

Lakeman, R. (2019), "The myth of the well-known client", Issues in Mental Health Nursing, Vol. 40, No. 2, pp. 191-3. 
Lamy, A.T.G. (2015). Percepção das Relações de Cooperação em Ensaios Clínicos entre Organizações Farmacêuticas em Portugal - Aplicação da Janela de Johari, Mestrado, Lisbon School of Economics \& Management, Universidade de Lisboa, Lisboa, PT.

Lerner, J.E. (2020), "Social workers can't be republicans": engaging conservative students in the classroom", Journal of Social Work Education, Vol. 56, No. 1, pp. 56-67.

Lima, A. (2012), A Liderança Segundo Maquiavel, Clube de Autores, Belo Horizonte.

Littlejohn, S.W. (1978), Theories of Human Communication, Merrill, Columbus, Ohio.

Lo, M., Wang, Y., Constance, R. et al. (2016), "The critical success factors for organizational performance of SMEs in Malaysia: a partial least squares approach", Review of Business Management, Vol. 18, No. 61, pp. 370-91.

Lowes, R. (2020), "Knowing you: personal tutoring, learning analytics and the Johari Window", Frontiers in Education, Vol. 5, pp. 101.

Luft, J. (1970), "Introdução à dinâmica de grupos", Review of Business Management, Vol. 18, No. 61, pp. 37091.

Luft, J. and Ingham, H. (1955), The Johari Window, a Graphic Model for Interpersonal Relations, Western Training Laboratory for Group Development, University of California, Los Angeles.

Luong, M.G. and McLaughlin, A.C. (2011), "Improving communication of usability perceptions: an analysis of a Modified-Johari window as a tool for software designers", Proceedings of the Human Factors and Ergonomics Society Annual Meeting, Vol. 55, No. 1, pp. 1962-6.

Malloy, T.E. and Janowski, C.L. (1992), "Perceptions and metaperceptions of leadership: components, accuracy, and dispositional correlations", Personality and Social Psychology Bulletin, Vol. 18, No. 6, pp. 700-8.

Miguel, P.A.C. (2018), Metodologia de Pesquisa em Engenharia de Produção e Gestão de Operações, Elsevier, Rio de Janeiro.

Oliveira, M.A., Possamai, O. and Valentina, L.V.O.D. (2015), "Profile and Leadership tendences of a Brazilian worldwide leading Company", Production, Vol. 25, No. 2, pp. 379-90.

Osmanoğlu, D.E. (2019), "Expansion of the Open Area (Johari Window) and Group Work Directed to Enhancing the Level of Subjective Well-being", Journal of Education and Training Studies, Vol. 7, No. 5, pp. 76-85.

Pereira, C., Anholon, R. and Batocchio, A. (2017), "Obstacles and difficulties implementing the lean philosophy in Brazilian enterprises", Brazilian Journal of Operations \& Production Management, Vol. 14, No. 2, pp. 218-27.

Ramani, S., McMahon, G.T. and Armstrong, E.G. (2019), "Continuing professional development to foster behavior change: from principles to practice in health professions education", Medical Teacher, Vol. 41, No. 9, pp. 1045-105.

Rodrigues, A.F.C. and Veloso, A.L.O.M. (2013), "Organization trust, risk and creativity", Review of Business Management, Vol. 15, No. 49, pp. 545-61.

Russo, G. and Tomei, P. (2015), "Alignment of cultural agreement practices in a brazilian based company", Brazilian Journal of Operations \& Production Management, Vol. 12, No. 1, pp. 26-39.

Sagiyanto, A. and Ardiyanti. N. (2018), "Self Disclosure Melalui Media Social Instagram (Studi Kasus Pada Anggota Galeri Quote)", Nyimak: Journal of Communication, vol. 2, no. 1, pp. 81-94.

Shamoa-Nir, L. (2017), "The window becomes a mirror: the use of the Johari Window model to evaluate stereotypes in intergroup dialogue in Israel", Journal Israel Affairs, Vol. 23, No. 4, pp. 727-46.

Suryani, I. and Siregar, M.S. (2020), "Pendekatan Teknik Johari Window Dalam Menangani Kesulitan Belajar Siswa di SMP Al-Hidayah Medan", Al-Irsyad, vol. 10, n. 1, pp. 1-8.

Tseng, E.K., Jo, D., Shih, A.W. et al. (2018), "Window to the unknown: using storytelling to identify learning needs for the intrinsic competencies within an online needs assessment", AEM Education and Training, Vol. 3, No. 2, pp. 179-87.

van Dick, R., Fink, L., Steffens, N.K. et al. (2018), "Attributions of leaders' charisma increase after their death: The mediating role of identity leadership and identity fusion", Leadership, Vol. 15, No. 5, pp. 576-89. 
Virtaharju, J.J. and Liiri, T.P. (2019), "The supervisors who became leaders: leadership emergence via changing organizational practices", Leadership, Vol. 15, No. 1, pp. 103-22.

Yin, R.K. (2015), Estudo de Caso: Planejamento e Métodos, Bookman, Porto Alegre.

Author contributions: All the authors contributed equally to this paper. 